ZOOLOGIA 30 (4): 437-440, August, 2013

http://dx.doi.org/10.1590/S1984-46702013000400010

\title{
Masteria manauara sp. nov., the first masteriine species from Brazil (Araneae: Dipluridae: Masteriinae)
}

\section{Rogério Bertani ${ }^{1,4}$, Wanessa Ribeiro $\mathrm{Cruz}^{2} \&$ Maria Ermelinda do Espírito Santo Oliveira ${ }^{3}$}

\author{
${ }^{1}$ Laboratório Especial de Ecologia e Evolução, Instituto Butantan. Avenida Vital Brazil 1500, 05503-900 São Paulo, SP, Brazil. \\ 2 Programa de Pós-graduação em Diversidade Biológica, Universidade Federal do Amazonas. \\ E-mail: wanessa_cruz@yahoo.com.br \\ ${ }^{3}$ Instituto de Ciências Biológicas, Universidade Federal do Amazonas. Avenida General Rodrigo Otávio Jordão Ramos 3000, \\ Campus Universitário,69077-000 Manaus, AM, Brazil.E-mail: ermeoliveira@uol.com.br \\ ${ }^{4}$ Corresponding author. E-mail: rbert@butantan.gov.br, rogerio.bertani@uol.com.br
}

\begin{abstract}
A new species of Masteria L. Koch, 1873 from Manaus, Brazil, Masteria manauara sp. nov., is herein described. The specimens were collected by hand or using litter bags in the leaf litter around Attalea attaleoides (Barb. Rodr.) palm trees. The new species resembles Masteria colombiensis Raven, 1981 by lacking paraembolic apophysis on male copulatory organs and having spiniform apophysis on the ventral metatarsus I. It differs in the tibial spur, made of two subdistal, spiniform and converging spurs. Females are unique in having two spermathecae with slender helicoidal stalks. Males and females have only six eyes, and are tiny, even when compared with other Masteria species.
\end{abstract}

KEY WORDS. Amazon; Attalea attaleoides; leaf litter; Mygalomorphae; taxonomy.

The Mygalomorphae comprises 2,731 species distributed in 16 families (PlatNick 2013) and is well-known for containing most of the largest spider species in the world, mainly in the Theraphosidae. However, Mygalomorphae also contains tiny species, some of which are amongst the smallest spider species ever recorded (Raven 1979, 1981, Raven \& Platnick 1981, Platnick \& Foster 1982), a less widely known curiosity. These tiny spiders live mainly in the leaf litter and are normally sampled using particular techniques such as berlese funnels and pit-fall traps (Raven 1979, 1981, Platnick \& Foster 1982). Only recently has the knowledge of this fauna increased, and several new species have been discovered.

One of the genera containing the smallest mygalomorph species is the diplurid Masteria L. Koch, 1873. Masteria comprises 22 species widely distributed in the Australasian Region and the New World: the Fiji Islands and Micronesia, M. hirsuta L. Koch, 1873 - type species; Phillipines, M. caeca Simon, 1892 and M. cavicola Simon, 1892; New Caledonia, M. franzi Raven, 1991 and M. kaltenbachi Raven, 1991; New Guinea, M. macgregori (Rainbow, 1898) and M. pallida (Kulczin'ski, 1908); and Australia, M. toddae Raven, 1979. In the New World, species were described from Cuba, M. aimeae (Alayón, 1995) and M. golovatchi Alayón, 1995; Jamaica, M. lewisi (Chickering, 1964) and M. pecki Gertsch, 1982; Puerto Rico, M. petrunkevitchi (Chickering, 1964); Saint Vincent, M. modesta (Simon, 1891); Trinidad, M. barona (Chickering, 1966) and M. simla (Chickering, 1966); Costa Rica and Panama, M. downeyi (Chickering, 1966) and M. spinosa (Petrunkevitch, 1925); Colombia, M. colombiensis Raven, 1981; and Venezuela, M. cyclops (Simon, 1889), M. lucifuga (Simon, 1889) and M. tovarensis (Simon, 1889).

Herein we describe the first masteriine species from Brazil, collected in Manaus, state of Amazonas.

\section{MATERIAL AND METHODS}

Specimens were collected in a "Terra Firme" primary forest patch in Manaus, state of Amazonas, Brazil, Fazenda Experimental from the Universidade Federal do Amazonas $\left(2^{\circ} 39^{\prime} 30.85^{\prime \prime} \mathrm{S}, 60^{\circ} 03^{\prime} 17.87^{\prime \prime} \mathrm{W}\right)$ in the leaf litter under and around the palm tree Attalea attaleoides (Barb. Rodr.) using two methods: direct hand collecting in the leaf litter and collecting with litter bags (SwiFT et al. 1979).

The general format for the descriptions follows RAVEN (1981) with some modifications; e.g., we provide the diameter of the eye in $\mathrm{mm}$ rather than,in ratios. All measurements are in millimeters and were obtained with a Leica LAS Interactive Measurements module. Leg and palp measurements were taken from the dorsal aspect of the left side (unless appendages were lost or obviously regenerated). A Leica LAS Montage and LAS 3D module mounted on a Leica M205C dissecting microscope were used to capture the images of spider structures. Spermathecae were drawn over images obtained with a Leica DM 2500 coumpound microscope. Abbreviations: (ALE) anterior lateral eyes, (AME) anterior median eyes, (ITC) inferior tarsal claw, (MOQ) median ocular quadrangle, (PLE) posterior lateral eyes, (PLS) posterior lateral spinnerets, (PME) posterior median eyes, 
(PMS) posterior median spinnerets, and (STC) superior tarsal claws. Specimens are deposited in the following institutions: INPA - Instituto de Pesquisas da Amazônia, Manaus, and MNRJ - Museu Nacional do Rio de Janeiro, Rio de Janeiro.

\section{TAXONOMY}

\section{Masteria manauara sp. nov.}

Figs 1-15

Diagnosis. Masteria manauara sp. nov. males differ from males of all other species in the genus by having six eyes (Figs 4 and 12), a tibial spur comprised by two subdistal ventral spurs slightly curved inwards (Figs 8 and 9), a proximal ventral spur on metatarsus I (Figs 8 and 9), and no paraembolic apophysis on palpal bulb (Figs 6 and 7). Females can be distinguished from those of all other species by having two spermathecae with slender, helicoidal stalk (Figs 14 and 15).

Description. Male holotype (INPA 8598). Entirely pallid. Carapace 0.69 long, 0.51 wide, clothed with long (0.07) prostate gray bristles on interstrial ridges (Figs 1 and 3); a long recurved bristle between ALE (Figs 3 and 4). Six eyes in a compact group on tubercle occupying 0.38 of head width (Fig. 4). Eye group 0.08 long, 0.12 wide. AME lacking. Sizes and interdistances: ALE 0.05, PME 0.02, PLE 0.05, ALE-ALE 0.01, ALE-PLE 0.08, PME-PLE 0.01, PME-PME 0.01, PLE-PLE 0.05, ALE-PME 0.09. MOQ front width 0.09 , back width 0.13 , length 0.08 . Chelicerae 0.26 long, 0.12 wide, with twelve widely spaced teeth on furrow promargin and four spinules mesobasally. Labium 0.05 long, 0.12 wide. Maxillae 0.17 long, 0.13 wide. Sternum 0.47 long, 0.37 wide; sigilla not evident (Fig. 2).

Palp with two apical spines on cymbium; bulb globose, tegulum 0.07 long, 0.06 wide, constricting abruptly and giving origin to a long (0.12) and thin (0.003) embolus (Figs 6 and 7). Leg lengths and midwidths in Table I.
Leg formula 4123. Tibia I with two subdistal ventral spurs slightly curved inwards. Metatarsus I with proximoventral spur (Figs 8 and 9). Spines elongate: leg I lacking spines; leg 2, tibia p1, v2, metatarsus p1, v2; leg 3, patella d1, tibia d1, p2, r1, v1, metatarsus d3, v1; leg 4, tibia d3, p2, r3, v3, metatarsus d3, r2, v1; palp, tarsus 2. Three-four teeth on STC; two teeth on ITC. Abdomen 0.79 long, 0.51 wide. Spinnerets (Fig. 5): PMS 0.12 long, 0.04 wide, 0.13 apart; basal, middle, and apical segments of PLS 0.17 long, 0.07 wide; 0.16 long, 0.07 wide; 0.16 long, 0.07 wide, respectively.

Female paratype (INPA 8600). As in male, except as noted.

Carapace 0.77 long, 0.60 wide, clothed with long (0.15) prostate gray bristles on interstrial ridges (Fig. 1). Six eyes in a compact group on tubercle occupying 0.33 of head width (Fig. 12). Eye group 0.09 long, 0.13 wide. AME lacking. Sizes and interdistances: ALE 0.06, PME 0.02, PLE 0.05, ALE-ALE 0.01, ALE-PLE 0.01, PME-PLE 0.01, PME-PME 0.01, PLE-PLE 0.04, ALE-PME 0.01. MOQ front width 0.11, back width 0.13, length 0.09 . Chelicerae 0.25 long, 0.15 wide, with nine widely spaced teeth on furrow promargin and three spinules mesobasally. Labium 0.07 long, 0.14 wide. Maxillae 0.2 long, 0.16 wide. Sternum 0.47 long, 0.41 wide; sigilla not evident (Fig. 11). Leg lengths and midwidths in Table II. Leg formula 4123. Spines elongate: leg I and palp lacking spines; leg 2, tibia p2, v2; leg 3, patella d3, tibia d1, p2, r2, v2, metatarsus d1, p2, r2, v2; leg 4, patella d1, tibia d1, p2, r2, v3, metatarsus d3, r2, v1. Abdomen 1.08 long, 0.74 wide. Spinnerets (Fig. 13): PMS 0.15 long, 0.06 wide, 0.21 apart; basal, middle, and apical segments of PLS 0.24 long, 0.09 wide; 0.17 long, 0.09 wide; 0.21 long, 0.07 wide, respectively. Epigastric plate not posteriorly produced; spermathecae two, receptacles rounded with slender helicoidal stalks (Figs 14 and 15).

Variation: carapace length - males (0.69-0.77, median 0.72 , standard deviation $0.04, \mathrm{n}=4)$; females $(0.69-0.84$, median 0.75 , standard deviation $0.05, \mathrm{n}=9$ ).

Table I. Masteria manauara sp. nov. Male holotype (INPA 8598). Length and midwidths of right legs and palpal segments.

\begin{tabular}{ccccccc}
\hline Length/Midwidths & Femur & Patella & Tibia & Metatarsus & Tarsus & Total (length) \\
\hline Pp & $0.27 / 0.01$ & $0.15 / 0.09$ & $0.22 / 0.1$ & - & $0.11 / 0.07$ & 0.75 \\
I & $0.51 / 0.14$ & $0.25 / 0.12$ & $0.38 / 0.12$ & $0.25 / 0.09$ & $0.23 / 0.09$ & 1.62 \\
II & $0.38 / 0.13$ & $0.24 / 0.11$ & $0.30 / 0.10$ & $0.24 / 0.08$ & $0.25 / 0.08$ & 1.41 \\
III & $0.41 / 0.12$ & $0.18 / 0.09$ & $0.24 / 0.09$ & $0.24 / 0.08$ & $0.21 / 0.05$ & 1.28 \\
IV & $0.53 / 0.13$ & $0.24 / 0.12$ & $0.40 / 0.09$ & $0.39 / 0.07$ & $0.29 / 0.05$ & 1.85 \\
\hline
\end{tabular}

Table II. Masteria manauara sp. nov. Female paratype (INPA 8600). Length and midwidths of right legs and palpal segments.

\begin{tabular}{ccccccc}
\hline Length/Midwidths & Femur & Patella & Tibia & Metatarsus & Tarsus & Total (length) \\
\hline Pp & $0.36 / 0.11$ & $0.23 / 0.10$ & $0.26 / 0.09$ & - & $0.26 / 0.07$ & 1.11 \\
I & $0.51 / 0.15$ & $0.33 / 0.13$ & $0.41 / 0.11$ & $0.38 / 0.09$ & $0.26 / 0.08$ & 1.89 \\
II & $0.48 / 0.15$ & $0.30 / 0.13$ & $0.32 / 0.10$ & $0.31 / 0.07$ & $0.23 / 0.07$ & 1.64 \\
III & $0.42 / 0.14$ & $0.25 / 0.10$ & $0.29 / 0.09$ & $0.33 / 0.07$ & $0.23 / 0.06$ & 1.52 \\
IV & $0.49 / 0.15$ & $0.29 / 0.15$ & $0.48 / 0.12$ & $0.47 / 0.10$ & $0.28 / 0.05$ & 2.01 \\
\hline
\end{tabular}


Type material. Male holotype, BrazIL, Amazonas: Manaus (Fazenda Experimental da UFAM, 2³9'30.85"S, 6003'17.87"W), 29.VI.2007, in litter bag on the base of Attalea attaleoides palm, Wanessa Cruz leg. (INPA 8598). Paratypes: BraziL, Amazonas: Manaus (Fazenda Experimental da UFAM, $2^{\circ} 39^{\prime} 30.85^{\prime \prime} \mathrm{S}$, 600'17.87"W), Wanessa Cruz leg., 2 females, 2 immatures, 13.III.2007 (INPA 8599), hand collecting; 1 female, 28.V.2007
(MNRJ 06531), litter bag; 2 females, 28.VIII.2007 (INPA 8600), litter bag; 1 female 1 immature, 29.VI.2007 (INPA 8601), litter bag; 1 immature, 28.VIII.2007 (INPA 8602), litter bag; 1 female, 13.III.2007 (INPA 8603), hand collecting; 1 female, 27.VII.2007 (MNRJ 06532), litter bag; 1 immature, 28 May 2007 (INPA 8604), litter bag; 1 immature, 28 May 2007 (INPA 8605), litter bag; 1 male, 23.III.2007 (MNRJ 06533), hand collecting; 1 male,
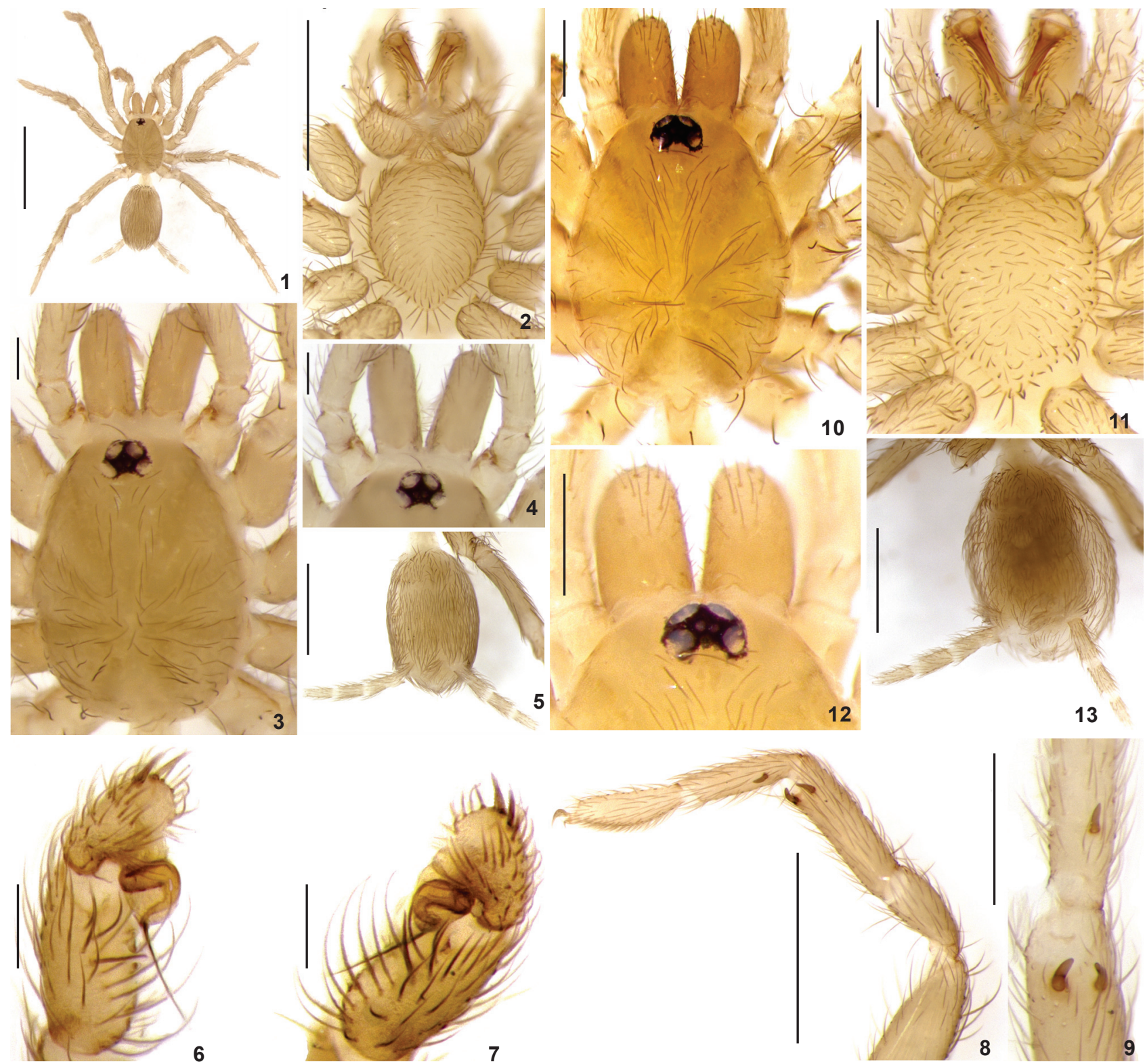

Figures 1-13. Masteria manauara sp. nov. (1-9) Holotype male (INPA 8598): (1) habitus; (2) sternum, maxillae and labium; (3) carapace and chelicerae; (4) eye tubercle and chelicerae; (5) abdomen and spinnerets, ventral; (6-7) rigth palp, (6) retrolateral, (7) prolateral; (89) rigth leg I spur, (8) prolateral, (9) ventral; (10-13) paratype female (INPA 8600): (10) carapace and chelicerae; (11) sternum, maxillae and labium; (12) eye tubercle; (13) abdomen and spinnerets, ventral. Scale bars: $1=1.0 \mathrm{~mm} ; 2,5,8$ and $13=0.5 \mathrm{~mm} ; 3,4$ and $6-7=$ $0.1 \mathrm{~mm}, 9-12=0.2 \mathrm{~mm}$. 


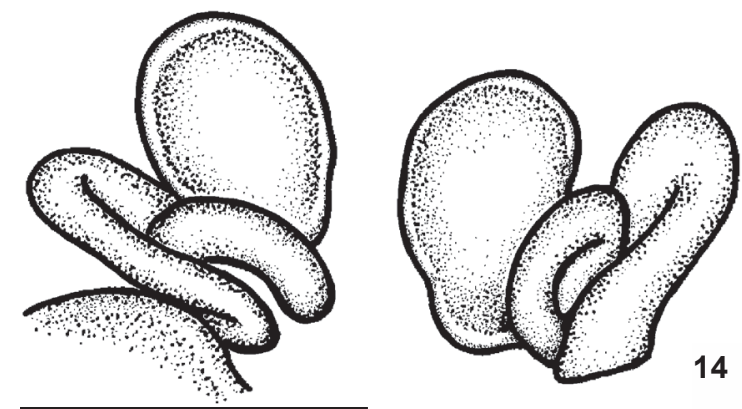

Figures 14-15. Masteria manauara sp. nov. Spermathecae, dorsal. (14) INPA 8608; (15) INPA 8599. Scale bar: $50 \mu$ m.
28.V.2007 (INPA 8606), litter bag; 1 immature, 29.VI.2007 (INPA 8607), litter bag; 1 male, 3 females, 1 immature, 23.III.2007 (MNRJ 06534), hand collecting; 1 female, 13.III.2007 (INPA 8608), hand collecting.

Distribution. Only known from type locality.

Etymology. The specific, manauara, honors the native inhabitant of the Manaus region in the state of Amazonas, Brazil.

Natural history. Masteria manauara sp. nov. is a common inhabitant in the leaf litter of the sampled area. Depending upon the method of collecting, it can be found in abundance colonizing different strata of leaf litter, representing $16.8 \%$ of the total abundance of the spiders collected (Cruz, unpublished data). It belongs to the guild of "litter stalkers," as do the species of Microstigmatidae, Oonopidae, Caponiidae and Palpimanidae (HöFER \& BREsCOVIT 2001), which are commonly found in leaf litter as well. Individuals of these families probably compete for resources with M. manauara sp. nov., since both have a tiny size and similar predation behavior.

\section{ACKNOWLEDGMENTS}

WRC and MEESO thank Thierry Ray Jehlen Gasnier for his suggestion regarding the study of the species and for coadvising WRC. We thank Júlio M.M. Wolff for helping with the field work, Izeni Pires for support with laboratory material, and Ana Lucia Tourinho (INPA) and Adriano Kury (MNRJ) for providing a repository for the types. Norman Platnick helped with literature. Support: Fapesp 2012/01093-0 for RB.

\section{LITERATURE CITED}

Höfer, H. \& A.D. BRescovit. 2001. Species and guild structure of a neotropical spider assemblage (Araneae) from Reserva Ducke, Amazonas, Brasil. Andrias 15: 99-119.

PlatnICK, N.I. 2013. The world spider catalog, version 13.5. American Museum of Natural History, available online at http://research.amnh.org/iz/spiders/catalog. DOI: 10.5531/ db.iz.0001. [Accessed: 18.I.2013].

Platnick, N.I. \& R.R. Foster. 1982. On the Micromygalinae, A New Subfamily of Mygalomorph Spiders (Araneae, Microstigmatidae). American Museum Novitates 2734: 1-13.

RAVEN, R.J. 1979. Systematics of the mygalomorph spider genus Masteria (Masteriinae: Dipluridae: Arachnida). Australian Journal of Zoology 27: 623-636.

RaVEn, R.J. 1981. Three new mygalomorph spiders (Dipluridae, Masteriinae) from Colombia. Bulletin of the American Museum of Natural History 170: 57-63.

Raven, R.J. \& Platnick, N.I. 1981. A revision of the American spiders of the family Microstigmatidae (Araneae, Mygalomorphae). American Museum Novitates 2707: 1-20.

Swift, M.J.; O.W. Heal \& J.M. Anderson. 1979. Decomposition in terrestrial ecosystems. Studies in Ecology 5. Oxford, Blackwell, 372p.

Submitted: 01.II.2013; Accepted: 13.IV.2013.

Editorial responsibility: Walter A.P. Boeger 